\title{
MANUAL BREW HOUSE BLEND COKLAT KHAS INDONESIA
}

\author{
R.A. Mochammad Deval ${ }^{1}$ \\ mochammad.deval@gmail.com \\ Sekolah Tinggi Pariwisata Bandung \\ Ridwan Iskandar ${ }^{1}$ \\ rii@stp-bandung.ac.id \\ Sekolah Tinggi Pariwisata Bandung \\ Hanna Daniati ${ }^{1}$ \\ hai@stp-bandung.ac.id \\ Sekolah Tinggi Pariwisata Bandung
}

\begin{abstract}
Experimental research in the form of making house blend chocolate by using chocolate originating from Indonesia, namely Java Srawana, Lampung Pesawaran and Sulawesi Celebes using the Manual Brew method using cezve tools. The goal is to get aspects of the original chocolate flavor image from chocolate blend and add interesting experiences in drinking original chocolate from Indonesia.

The research method used is an experimental research method. By making 3 house blend chocolate recipes and tested on 50 panelists. The data collection method is carried out by distributing questionnaires to panelists. Data analysis methods used were organoleptic test, Variant Analysis (ANOVA) and t test, Tukey B $^{\mathrm{a}}$, with the help of Microsoft Excel 2010 and SPSS.22 software (Statistical Product for Service Solution).

The results of this study were obtained, house blend chocolate with the composition of Lampung Pesawaran 6gr, Java Srawana 6gr and Sulawesi Celebes 8gr, received by all panelists from the aspects of aroma, flavor, acidity, bitterness, astringent (taste), caramelly, creamy, texture. Produces a real chocolate flavor with a banana-flavored sweet and slightly bitter, then accompanied by the smell of vanilla.
\end{abstract}

Key word : house blend chocolate, Manual Brew cezve, chocolate flavor aspects

\begin{abstract}
ABSTRAK
Penelitian eksperimen berupa pembuatan coklat house blend dengan menggunakan coklat yang berasal dari Indonesia yaitu Java Srawana, Lampung Pesawaran dan Sulawesi Celebes menggunakan metode Manual Brew memakai alat cezve. Tujuannya untuk mendapatkan aspek citra rasa coklat asli berasal dari perpaduan coklat dan menambah pengalaman menarik dalam meminum coklat asli dari Indonesia.

Metode penelitian yang digunakan adalah metode penelitian eksperimental. Dengan membuat 3 buah resep coklat house blend dan diujikan kepada 50 orang panelis. Metode pengumpulan data dilakukan dengan membagikan kuisioner kepada para panelis. Metode analisis data yang digunakan, yaitu uji organoleptik,
\end{abstract}


Analisis Varian (ANOVA) dan uji t, Tukey B ${ }^{\mathrm{a}}$, dengan bantuan Microsoft Excel 2010 dan software SPSS.22 (Statistical Product for Service Solution).

Hasil dari penelitian diperoleh, coklat house blend dengan komposisi Lampung Pesawaran 6gr, Java Srawana 6 gr dan Sulawesi Celebes 8gr, diterima oleh seluruh panelis dari aspek aroma, flavour, acidity, bitterness, astringent (rasa sepat), caramelly, creamy, texture. Menghasilkan rasa coklat asli beraroma pisang yang manis dan sedikit pahit, lalu diiringi dengan bau vanilla.

Kata kunci : coklat house blend, Manual Brew cezve, aspek citra rasa coklat

\section{PENDAHULUAN}

Seni mencampur beberapa jenis Single Origin coklat dari perkebunan yang ada di Indonesia untuk mendapatkan satu sajian minuman coklat khas Indonesia, terkenal dengan istilah House Blend Coklat. Minuman coklat dikenalkan dan dibawa oleh bangsa Eropa semenjak kedatangan mereka ke Indonesia pada abad 16, sehingga minuman coklat menjadi salah satu pilihan masyarakat Indonesia hingga sekarang ini selain kopi dan teh.

Racikan dan campuran dari beberapa single origin dan varietas bahan yang dipakai dikenal dengan istilah House Blend. Hal ini merupakan kreasi olahan racikan dari suatu tempat usaha seperti coffee shop, cafe atau toko. Sedangkan istilah single origin, yang berarti varietas atau jenis bahan dari suatu daerah tertentu. Racikan house blend dilakukan untuk mendapatkan suatu cita rasa yang baru daripada awalnya. Ramlah (2016:24) menyatakan faktor fermentasi dan pengeringan biji kakao dapat mempengaruhi rasa khas coklat. Konsep blend dapat dijelaskan dengan mencampur dan meracik berbagai bahan mentah atau bijih dengan berbagai takaran untuk memperoleh hasil campuran yang mempunyai takaran tertentu sesuai selera konsumen sebagai pembeli. House blend coklat yang akan dibuat adalah dengan mencampurkan beberapa single origin coklat dari beberapa daerah di Indonesia dan mengkombinasikannya menjadi suatu kesatuan.

Dalam artikel Paramitha dan Puspitasari (2018) dijelaskan bahwa coklat yang diambil dari satu tempat / daerah tertentu dapat dikatakan single origin.

Artinya coklat single origin diambil dari sumber atau pertanian di satu daerah tertentu. Indonesia memiliki berbagai macam single origin coklat, tumbuh di bebeberapa daerah dari sabang sampai merauke.

Dua produsen lokal yaitu Dilco dan Korte menjelaskan perbedaan karakter dan rasa yang ditimbulkan oleh coklat single origin dari berbagai daerah di Indonesia setelah diolah dapat diliat pada tabel 1. Sesuai penjelasan Misnawi dan Jinap, 2008 bahwa rasa khas coklat merupakan kombinasi rasa dasar pahit, asam, dan manis yang seimbang, tersusun dari komponen - komponen unik dalam coklat. Kemudian artikel dari Pashmina (2016) mengatakan, rasa coklat dilihat dari berbagai aspek seperti texture, smell, sour, flavour dan finish. Sehingga karakteristik dari antara racikan atau olahan coklat tidak berbeda jauh dengan dengan racikan atau olahan kopi. Berikut data beberapa coklat single origin dari berbagai daerah di Indonesia : 
Tabel 1

Single Origin Coklat Indonesia

\begin{tabular}{|c|l|l|}
\hline No & \multicolumn{1}{|c|}{ Variant } & \multicolumn{1}{|c|}{ Notes } \\
\hline 1 & $\begin{array}{l}\text { Bali Kamarasa 65\% Cacao Content } \\
\text { Product by Dillco }\end{array}$ & Light, \& Nutty \\
\hline 2 & $\begin{array}{l}\text { Bali Samsaman 60\% Cacao Content } \\
\text { Product by Korte }\end{array}$ & $\begin{array}{l}\text { Bright, Floral, Fruit, } \\
\text { \& Silk }\end{array}$ \\
\hline 3 & $\begin{array}{l}\text { Borneo Pulau Sapi 70\% Cacao Content } \\
\text { Product by Korte }\end{array}$ & $\begin{array}{l}\text { Bold, Full-bodied, \& } \\
\text { Strong Roasted Nuts }\end{array}$ \\
\hline 4 & $\begin{array}{l}\text { Java Srawana 65\% Cacao Content } \\
\text { Product by Dillco }\end{array}$ & $\begin{array}{l}\text { Bittersweetness \& } \\
\text { Berry Like }\end{array}$ \\
\hline 5 & $\begin{array}{l}\text { Lampung Pesawaran 70\% Cacao } \\
\text { Content Product by Korte }\end{array}$ & $\begin{array}{l}\text { Bold, Strong, Ripe } \\
\text { Banana Fruitness }\end{array}$ \\
\hline 6 & $\begin{array}{l}\text { Sulawesi Celebes 65\% Cacao Content . } \\
\text { Product by Dillco }\end{array}$ & $\begin{array}{l}\text { Explicit, \& Vanilla } \\
\text { Like }\end{array}$ \\
\hline 7 & $\begin{array}{l}\text { Sumatera Andalas 65\% Cacao Content } \\
\text { Product by Dillco }\end{array}$ & Bold, \& Tropical \\
\hline
\end{tabular}

Sumber : observasi peneliti (2019)

Dalam penyajian minuman kopi, kita mengenal metode Manual Brew, yaitu suatu seni menyeduh atau menyajikan kopi dengan cara manual, tanpa menggunakan mesin. Seni manual brewing memiliki metode yang kompleks, namun metode seduh ini dalam penentuan rasa hanya memiliki andil 10\% - 15\%, selebihnya ditentukan oleh jenis biji kopi dan tingkat penyangraian biji kopi (Knox, 1997:126). Saat ini sudah banyak berbagai macam alat diciptakan dalam perkembangan penyajian dan penyeduhan Manual Brewing, alat - alat itu diantaranya, yaitu V60, Aeropress, French Press, Moka pot, Syphon, Chemex, Cezve, dan lain - lain

Salah satu alat manual brewing yang akan digunakan dalam eksperimen ini adalah Cezve. McWilliams (2015:317) menjelaskan metode cezve adalah merebus kopi menggunakan pot special dengan ukuran kecil dan api kecil. Metode Cezve biasa digunakan di Turki , merupakan salah satu alat manual brewing tertua dalam sejarah penyeduhan kopi, alat ini sudah ditemukan pada abad ke-15.

Sesuai penjelasan tentang house blend, single origin coklat dan manual brew, penulis akan melakukan suatu eksperimen berupa pembuatan house blend coklat dengan mencampur atau meracik coklat asli Indonesia berasal dari daerah atau single origin yaitu Sulawesi Celebes, Lampung Pesawaran dan Java Srawana. Hal ini dapat menjadikan produk coklat lokal Indonesia menjadi kaya akan rasa, bervariasi dan lebih diterima oleh masyarakat Indonesia. Metode manual brew dengan menggunakan alat cezve dipakai dalam penyajian eksperimen ini. Bertujuan untuk mendapatkan aspek citra rasa coklat asli langsung berasal dari penyeduhan coklat tersebut. Bagi para penikmat coklat serta masyarakat umum hasil eksperimen ini dapat menambah pengalaman menarik dalam meminum coklat asli dari Indonesia. Topik yang dibahas adalah Manual Brew House Blend coklat khas Indonesia. 


\section{METODOLOGI}

Jenis penelitian ini adalah penelitian kuantitatif dengan metode eksperimen. Penelitian kuantitatif merupakan penelitian dengan data berupa angka-angka dan analisis menggunakan statistik. Sedangkan metode eksperimen merupakan metode penelitian yang digunakan untuk mencari pengaruh treatment (perlakuan) tertentu terhadap yang lain dalam kondisi yang terkendalikan (Sugiyono, 2012:107). Desain eksperimen merupakan langkah-langkah yang perlu diambil jauh sebelum eksperimen dilakukan agar data yang semestinya diperlukan dapat diperoleh, sehingga akan membawa pada analisis objektif dan kesimpulan yang berlaku untuk persoalan yang sedang dibahas (Sugiyono, 2012:72).

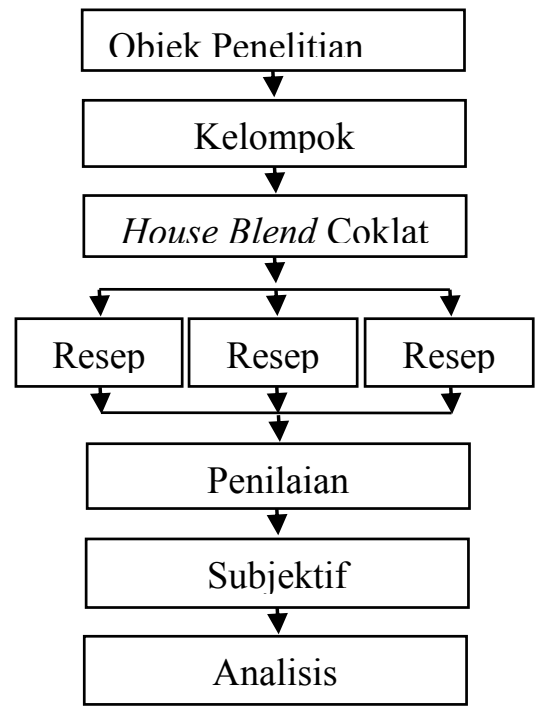

\section{Gambar 1: Desain Eksperimen}

Eksperimen ini dilakukan melaui observasi bahan dan alat didukung melaui studi pustaka, dilengkapi dengan dokumentasi hasil kegiatan ekperimen serta ketiga resep eksperimen selanjutnya di uji organoleptik kepada 50 orang yang terdiri dari pengelola kafe, akademisi dan masyarakat umum melalui kuesioner. Pengujian dilakukan dengan menggunakan Uji LSD (Least Significance Difference) kepada responden sebanyak 3 sampel pembuatan Manual Brewing House Blend coklat.

Penilaian diberikan berdasarkan delapan karakteristik yaitu aroma, flavour, acidity, bitterness, astringent (rasa sepat), caramelly, creamy, texture (Yusriana, dan Jaya 2015:1) dan (Ramlah 2016:23), untuk menghasilkan suatu formulasi terbaik dari 3 resep yang disajikan. Hasil penilaian selanjutnya dianalisis untuk mengetahui tingkat kesukaan masyarakat terhadap sampel yang diujikan dan tentunya dapat mengetahui sajian resep Manual Brewing House Blend coklat hasil ekperimen yang disukai dan diminati.

Untuk mengetahui hal tersebut maka dilakukan dengan cara menganalisis data kualitatif hasil uji inderawi yang telah diperoleh dari panelis untuk dijadikan data kuantitatif. Adapun langkah-langkah untuk menghitung rerata skor adalah sebagai berikut dengan kualitas inderawi yang akan dinilai adalah nilai tertinggi $=$ 5 dan Nilai terendah $=1$, dengan jumlah panelis keseluruhan $=50$. 
Berdasarkan hasil olahan nilai perhitungan, maka akan diperoleh tabel interval dan kriteria hasil dari eksperimen sajian Manual Brewing House Blend coklat adalah sebagai berikut:

Tabel 2

Interval Penilaian Organoleptik Berdasarkan Aspek - Aspek

\begin{tabular}{|c|c|c|c|c|c|c|}
\hline \multirow{2}{*}{ No } & \multirow{2}{*}{ Aspek } & \multicolumn{5}{|c|}{ Rata - rata nilai } \\
\hline & & $1-1,7$ & $1,8-2,5$ & $2,6-3,3$ & $3,4-4,1$ & $4,2-5$ \\
\hline 1 & Aroma & $\begin{array}{c}\text { Aroma } \\
\text { vanilla } \\
\text { tidak ada }\end{array}$ & $\begin{array}{l}\text { Aroma } \\
\text { vanilla } \\
\text { kurang }\end{array}$ & $\begin{array}{l}\text { Aroma } \\
\text { vanilla } \\
\text { cukup } \\
\text { kuat }\end{array}$ & $\begin{array}{c}\text { Aroma } \\
\text { vanilla } \\
\text { kuat }\end{array}$ & $\begin{array}{c}\text { Aroma } \\
\text { vanilla } \\
\text { sangat } \\
\text { kuat }\end{array}$ \\
\hline 2 & Flavour & $\begin{array}{c}\text { Rasa } \\
\text { pisang } \\
\text { tidak ada }\end{array}$ & $\begin{array}{c}\text { Rasa } \\
\text { pisang } \\
\text { kurang }\end{array}$ & $\begin{array}{l}\text { Rasa } \\
\text { pisang } \\
\text { cukup } \\
\text { kuat }\end{array}$ & $\begin{array}{c}\text { Rasa } \\
\text { pisang } \\
\text { kuat }\end{array}$ & $\begin{array}{c}\text { Rasa } \\
\text { pisang } \\
\text { sangat } \\
\text { kuat }\end{array}$ \\
\hline 3 & Acidity & $\begin{array}{c}\text { Keasaman } \\
\text { sangat } \\
\text { tidak kuat }\end{array}$ & $\begin{array}{l}\text { Keasaman } \\
\text { tidak kuat }\end{array}$ & $\begin{array}{c}\text { Keasaman } \\
\text { cukup } \\
\text { kuat }\end{array}$ & $\begin{array}{c}\text { Keasaman } \\
\text { kuat }\end{array}$ & $\begin{array}{c}\text { Keasaman } \\
\text { sangat } \\
\text { kuat }\end{array}$ \\
\hline 4 & Bitterness & $\begin{array}{c}\text { Rasa pahit } \\
\text { sangat } \\
\text { tidak kuat }\end{array}$ & $\begin{array}{l}\text { Rasa pahit } \\
\text { tidak kuat }\end{array}$ & $\begin{array}{c}\text { Rasa pahit } \\
\text { cukup } \\
\text { kuat }\end{array}$ & $\begin{array}{c}\text { Rasa pahit } \\
\text { kuat }\end{array}$ & $\begin{array}{c}\text { Rasa pahit } \\
\text { sangat } \\
\text { kuat }\end{array}$ \\
\hline 5 & Astringent & $\begin{array}{l}\text { Rasa sepat } \\
\text { sangat } \\
\text { tidak kuat }\end{array}$ & $\begin{array}{l}\text { Rasa sepat } \\
\text { tidak kuat }\end{array}$ & $\begin{array}{c}\text { Rasa sepat } \\
\text { cukup } \\
\text { kuat }\end{array}$ & $\begin{array}{c}\text { Rasa } \\
\text { sepat kuat }\end{array}$ & $\begin{array}{c}\text { Rasa sepat } \\
\text { sangat } \\
\text { kuat }\end{array}$ \\
\hline 6 & Caramelly & $\begin{array}{c}\text { Rasa } \\
\text { karamel } \\
\text { sangat } \\
\text { tidak kuat }\end{array}$ & $\begin{array}{c}\text { Rasa } \\
\text { karamel } \\
\text { tidak kuat }\end{array}$ & $\begin{array}{c}\text { Rasa } \\
\text { karamel } \\
\text { cukup } \\
\text { kuat }\end{array}$ & $\begin{array}{c}\text { Rasa } \\
\text { karamel } \\
\text { kuat }\end{array}$ & $\begin{array}{c}\text { Rasa } \\
\text { karamel } \\
\text { sangat } \\
\text { kuat }\end{array}$ \\
\hline 7 & Creamy & $\begin{array}{l}\text { Creamy } \\
\text { tidak kuat }\end{array}$ & $\begin{array}{c}\text { Creamy } \\
\text { kurang } \\
\text { kuat }\end{array}$ & $\begin{array}{c}\text { Creamy } \\
\text { cukup } \\
\text { kuat }\end{array}$ & $\begin{array}{c}\text { Creamy } \\
\text { kuat }\end{array}$ & $\begin{array}{c}\text { Creamy } \\
\text { sangat } \\
\text { kuat }\end{array}$ \\
\hline 8 & Texture & $\begin{array}{c}\text { Tekstur } \\
\text { tidak } \\
\text { halus }\end{array}$ & $\begin{array}{c}\text { Tekstur } \\
\text { sedikit } \\
\text { halus }\end{array}$ & $\begin{array}{c}\text { Tekstur } \\
\text { halus } \\
\text { sedang }\end{array}$ & $\begin{array}{c}\text { Tekstur } \\
\text { halus }\end{array}$ & $\begin{array}{c}\text { Tekstur } \\
\text { sangat } \\
\text { halus }\end{array}$ \\
\hline
\end{tabular}

Sumber : Yusriana, dan Jaya 2015, Ramlah 2016, diolah Penulis, 2019

Untuk mengetahui kualitas keseluruhan maka hasil dari perhitungan tersebut akan diperoleh interval skor dan kriteria kualitas dari sajian Manual Brewing House Blend coklat sebagai berikut:

$4,2-5,0 \quad$ : Sangat berkualitas secara inderawi

$3,4-4,2 \quad$ : Berkualitas secara inderawi

2,6-3,4 : Cukup berkualitas secara inderawi

$1,8-2,6 \quad$ : Kurang berkualitas secara inderawi

$1,0-1,8 \quad$ : Tidak berkualitas secara inderawi 


\section{Metode Pelaksanaan Eksperimen}

Dalam melaksanakan eksperimen, langkah - langkah yang harus dilakukan untuk membuat Manual Brewing House Blend coklat adalah sebagai berikut :

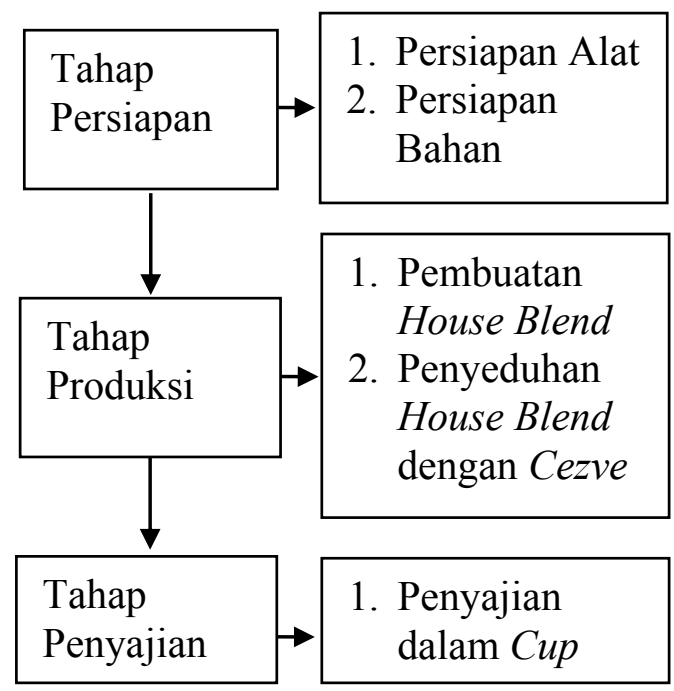

Gambar 2: Tahapan Eksperimen

\section{Tahap Persiapan}

Tahap ini adalah langkah awal dalam melakukan eksperimen, dimana kita akan mempersiapkan alat yaitu digital scale, sendok teh, gelas, cezve, stove \& gas dan cangkir. Bahan - bahan, yaitu coklat Java Srawana, Lampung Pesawaran, Sulawesi Celebes, dan Air.

Berdasarkan fakta dan keunikan mengenai coklat - coklat tersebut, peneliti membuat sebuah campuran yang disebut dengan House Blend. Dengan takaran atau rasio yang sesuai dengan standar penyajian yang tertera dalam kemasan coklat dan wawancara dari pengelola café di Bandung yang sering menggunakan coklat coklat kemasan tersebut. Peneliti menggunakan perbandingan (2:1) dimana 2 mewakili 20 gram House Blend dan 1 mewakili 100ml air untuk di seduh dengan metode manual brewing. Peneliti membuat 3 sampel dengan perbandingan House Blend yang memiliki ratio blending yang berbeda yaitu :

Tabel 3

House Blend Sampel Ratio/20 Gram

\begin{tabular}{|c|c|c|c|}
\hline $\begin{array}{c}\text { Single Origin } \\
\text { Coklat }\end{array}$ & \multicolumn{3}{|c|}{ Ratio/20gr } \\
\hline $\begin{array}{c}\text { Lampung } \\
\text { Pesawaran }\end{array}$ & $8 \mathrm{gr}$ & $6 \mathrm{gr}$ & $6 \mathrm{gr}$ \\
\hline Java Srawana & $6 \mathrm{gr}$ & $6 \mathrm{gr}$ & $8 \mathrm{gr}$ \\
\hline $\begin{array}{c}\text { Sulawesi } \\
\text { Celebes }\end{array}$ & $6 \mathrm{gr}$ & $8 \mathrm{gr}$ & $6 \mathrm{gr}$ \\
\hline $\begin{array}{c}\text { House Blend } \\
\text { Sampel }\end{array}$ & $\begin{array}{c}\text { Sampel } \\
633\end{array}$ & $\begin{array}{c}\text { Sampel } \\
424\end{array}$ & $\begin{array}{c}\text { Sampel } \\
257\end{array}$ \\
\hline
\end{tabular}

Sumber : Olahan Penulis 


\section{Tahap Produksi}

1. Letakkan gelas diatas scale dan atur scale agar memulai penghitungan gramasi dari angka 0

2. Masukkan single origin coklat kedalam gelas, sesuai dengan takaran pada tiap - tiap sampel yang terdapat pada tabel 3 tentang resep eksperimen.

3. Letakkan gelas lain diatas scale dan atur ulang angka yang terdapat pada scale menjadi 0, dan masukkan air hingga mencapai 100ml

4. Masukkan House Blend yang sudah ditakar dan air kedalam cezve.

5. Aduk hingga house blend coklat hingga benar - benar larut dan tidak menyisakan coklat bubuk yang tersisa. Usahakan agar semua gelembung yang terdapat di permukaan hilang.

6. Aduk hingga house blend coklat hingga benar - benar larut dan tidak menyisakan coklat bubuk yang tersisa. Usahakan agar semua gelembung yang terdapat di permukaan hilang.

7. Tunggu hingga coklat memiliki tekstur seperti gambar diatas, dan coklat mulai berbuih, segera angkat dari kompor.

8. Lakukan langkah 1 sampai 7 untuk 2 sampel selanjutnya.

\section{Tahap Penyajian}

Setelah melalui tahap produksi, maka kita masuk ke tahap terakhir, yaitu tahap penyajian. Pada tahap ini, proses yang akan dilakukan adalah :

1. Siapkan cangkir, dan tuangkan house blend kedalam cup.

2. Segera sajikan kepada tamu setelah house blend selesai dibuat.

\section{HASIL PENELITIAN DAN PEMBAHASAN}

Hasil dari uji coba eksperimen sajian manual brewing house blend coklat akan diujikan kepada para responden sebanyak 50 orang. Mereka pelaku usaha / pengelola dari produsen coklat yaitu Dilco dan Korte dimana penguji menggunakan produknya sebagai bahan uji eksperimen, Dosen dan mahasiswa yang berminat mempelajari tentang coklat dan masyarakat umum yang ditemui di kafe dimana produk tersebut dijual. Hal ini untuk mengetahui tingkat kesukaan mereka kepada karekterisitik yang ditimbulkan. Seluruh reponden ini sama sekali belum pernah meminum coklat olahan ( house blend ) yang orisinal tanpa adanya campuran susu seperti biasanya ada di pasaran. Sehingga penilaian mereka dapat memberikan informasi hasil dari uji eksperimen ini.

Pada uji eksperimen ini peneliti memberikan 3 buah sampel dengan memberikan kode pada tiap - tiap sampel dengan tulisan 3 buah angka yaitu berdasarkan standar resep yang dibuat pada tabel 3. Resep 1 dengan kode angka 633, resep 2 dengan kode angka 424 dan resep 3 dengan angka 257. Hasil penyajiannya dapat dilihat pada gambar berikut ini : 


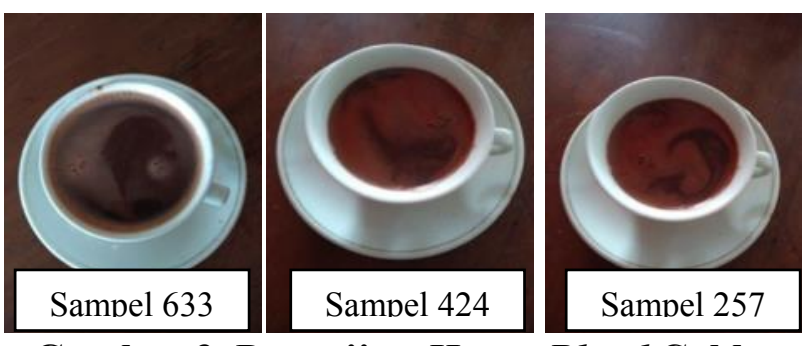

Gambar 3. Penyajian House Blend Coklat

Para panelis akan menilai karakteristik dari minuman coklat yaitu aroma, flavour, acidity, bitterness, astringent (rasa sepat), caramelly, creamy, texture. Hasil dari uji panelis dengan total jumlah 50 orang sebagai berikut :

\section{a. Aroma}

Aroma adalah bau yang ditimbulkan oleh rangsangan. Aroma banyak menentukan kelezatan makanan dan mempengaruhi penerimaan (Winarno, 2004). Aroma yang diterima oleh hidung dan direspon oleh otak, lebih banyak merupakan berbagai ramuan atau campuran empat bau utama yaitu harum, asam, tengik dan hangus. Komponen-komponen aroma cokelat terbentuk mulai penyangraian biji kakao dari calon-calon pembentuk citarasa seperti asam amino, peptide, gula pereduksi dan kuinon. Komponen-komponen tersebut termasuk dalam golongan alcohol, eter, furan, tiazol, piron, asam, ester, aldehida, imin, amin, oksazol, pirazin, dan pirol. (Misnawi dan Jinap 2008 dalam Ramlah, 2016:28). Berdasarkan hasil uji organoleptic, Aroma house blend coklat ini menghasilkan aroma vanila, sehingga responden menilai produk mana bersadasarkan pendapatnya yang memiliki aroma terbaik.

Berdasarkan hasil pengolahan data dengan menggunakan ANOVA dan uji lanjutan LSD (Least significant differense) serta uji lanjutan turkey's-b dengan selang kepercayaan $95 \%$ atau 0,05 menghasilkan karakteristik aroma yang terpilih pada kode 424 sebesar 4.2000 dengan hasil significant $>0,05$ menyatakan berbeda nyata baik dengan kode 257 maupun dengan kode 633 menurut uji turkey's- $b$. Hasil rata-rata dari uji dapat dilihat pada tabel berikut ini :

Tabel 4.

Deskripsi Hasil Olahan Kuesioner Pada Aspek Aroma

\begin{tabular}{|c|c|c|c|c|c|c|c|c|}
\hline & & & & & \multicolumn{2}{|c|}{$\begin{array}{c}\text { 95\% Confidence } \\
\text { Interval for Mean }\end{array}$} & \multirow{2}{*}{ Min } & \multirow{2}{*}{ Max } \\
\cline { 5 - 8 } & $N$ & Mean & $\begin{array}{c}\text { Std. } \\
\text { Dev }\end{array}$ & $\begin{array}{c}\text { Std. } \\
\text { Error }\end{array}$ & $\begin{array}{l}\text { Lower } \\
\text { Bound }\end{array}$ & $\begin{array}{c}\text { Upper } \\
\text { Bound }\end{array}$ & & \\
\hline 257 & 50 & 3.0200 & .71400 & .10097 & 2.8171 & 3.2229 & 2.00 & 4.00 \\
\hline 424 & 50 & 4.2000 & .72843 & .10302 & 3.9930 & 4.4070 & 3.00 & 5.00 \\
\hline 633 & 50 & 2.2200 & .81541 & .11532 & 1.9883 & 2.4517 & 1.00 & 5.00 \\
\hline Total & 150 & 3.1467 & 1.10755 & .09043 & 2.9680 & 3.3254 & 1.00 & 5.00 \\
\hline
\end{tabular}


Tabel 5.

Uji Anova Pada Aspek Aroma

\begin{tabular}{|l|r|r|r|r|r|}
\hline & $\begin{array}{r}\text { Sum of } \\
\text { Squares }\end{array}$ & \multicolumn{1}{c|}{ Df } & $\begin{array}{c}\text { Mean } \\
\text { Square }\end{array}$ & F & Sig. \\
\hline Between Groups & 99.213 & 2 & 49.607 & 87.269 & .000 \\
\hline Within Groups & 83.560 & 147 & .568 & & \\
\hline Total & 182.773 & 149 & & & \\
\hline
\end{tabular}

Tabel 6.

Pengaruh Perbandingan Resep Pada Aspek Aroma

\begin{tabular}{|l|l|l|r|}
\hline & Kode & $\mathrm{N}$ & \multicolumn{1}{|c|}{$\begin{array}{l}\text { Subset for } \\
\text { alpha }=0.05\end{array}$} \\
\hline \multirow{2}{*}{$\begin{array}{l}\text { Tukey } \\
\mathrm{B}^{\mathrm{a}}\end{array}$} & 257 & 50 & 3.0200 \\
\cline { 2 - 4 } & 424 & 50 & 4.2000 \\
\cline { 2 - 4 } & 633 & 50 & 2.2200 \\
\hline
\end{tabular}

\section{B. Taste}

Hasil manual brew dengan suhu yang tinggi menghasilkan terjadinya reaksi oksidasi flavonoid yang akan membantu pembentukan taste dan memberikan rasa khas cokelat yang akan semakin tajam. Chocolate flavour was classified as strong, moderate and weak, whereas other flavour descriptors were classified as acidic, bitter, fruity, burnt, hammy, musty, nutty and sweet. Jinap.et.al.(1995:106).

Pada hasil eksperimen ini selain ada aroma vanila juga memberikan rasa pisang yang sangat kuat. Dengan penilaian para penelis dan didukung dengan hasil pengolahan data dengan menggunakan ANOVA dan uji lanjutan LSD (Least significant differense) serta uji lanjutan turkey's-b dengan selang kepercayaan 95\% atau 0,05 menghasilkan karakteristik flavour yang terpilih pada kode 424 sebesar 4.620 dengan hasil significant $>0,05$ menyatakan berbeda nyata baik dengan kode 257 maupun dengan kode 633 menurut uji turkey's-b. Hasil rata-rata dari uji dapat dilihat pada tabel berikut ini :

Tabel 7.

Deskripsi Hasil Olahan Kuesioner Pada Aspek Taste

\begin{tabular}{|c|c|c|c|c|c|c|c|c|}
\hline \multirow{2}{*}{ 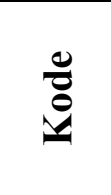 } & \multirow{2}{*}{$\boldsymbol{N}$} & \multirow{2}{*}{ Mean } & \multirow{2}{*}{$\begin{array}{l}\text { Std. } \\
\text { Dev }\end{array}$} & \multirow{2}{*}{$\begin{array}{c}\text { Std. } \\
\text { Error }\end{array}$} & \multicolumn{2}{|c|}{$\begin{array}{l}\text { 95\% Confidence } \\
\text { Interval for Mean }\end{array}$} & \multirow{2}{*}{ Min } & \multirow{2}{*}{$\operatorname{Max}$} \\
\hline & & & & & $\begin{array}{l}\text { Lower } \\
\text { Bound }\end{array}$ & $\begin{array}{l}\text { Upper } \\
\text { Bound }\end{array}$ & & \\
\hline 257 & 50 & 3.3600 & .48487 & .06857 & 3.2222 & 3.4978 & 3.00 & 4.00 \\
\hline 424 & 50 & 4.6200 & .49031 & .06934 & 4.4807 & 4.7593 & 4.00 & 5.00 \\
\hline 633 & 50 & 2.6200 & .80534 & .11389 & 2.3911 & 2.8489 & 1.00 & 4.00 \\
\hline Total & 150 & 3.5333 & 1.02758 & .08390 & 3.3675 & 3.6991 & 1.00 & 5.00 \\
\hline
\end{tabular}


Tabel 8.

Uji Anova Pada Aspek Taste

\begin{tabular}{|l|r|r|r|r|r|}
\hline & $\begin{array}{c}\text { Sum of } \\
\text { Squares }\end{array}$ & \multicolumn{1}{|c|}{ Df } & $\begin{array}{c}\text { Mean } \\
\text { Square }\end{array}$ & F & Sig. \\
\hline Between Groups & 102.253 & 2 & 51.127 & 136.449 & .000 \\
\hline Within Groups & 55.080 & 147 & .375 & & \\
\hline Total & 157.333 & 149 & & & \\
\hline
\end{tabular}

Tabel 9.

Pengaruh Perbandingan Resep Pada Aspek Taste

\section{Acidity}

\begin{tabular}{|l|l|l|r|}
\hline & Kode & N & \multicolumn{2}{|c|}{$\begin{array}{l}\text { Subset for } \\
\text { alpha }=0.05\end{array}$} \\
\hline \multirow{2}{*}{$\begin{array}{l}\text { Tukey } \\
\mathrm{B}^{\mathrm{a}}\end{array}$} & 257 & 50 & 3.3600 \\
\cline { 2 - 4 } & 424 & 50 & 4.6200 \\
\cline { 2 - 4 } & 633 & 50 & 2.6200 \\
\hline & & & \\
\hline
\end{tabular}

Acidity (citarasa asam) yang dihasilkan pada produk cokelat ditimbulkan karena adanya asam yang tersisa akibat dari tidak seluruhnya menguap pada saat proses pengolahan cokelat, terutama pada saat proses penyangraian dan concing. Senyawa asam dalam biji kakao adalah asam-asam organic yaitu asam laktat, suksinik, malik /malat, oksalat dan tartarat (Misnawi dan Jinap, 2008 dalam Ramlah 2016:29). Rasa asam merupakan atribut penting yang berkontribusi secara nyata terhadap keseluruhan cita rasa pasta kakao. Kehadiran rasa asam dalam jumlah sedikit akan menyumbang keseimbangan cita rasa pasta kakao, namun apabila pada jumlah yang lebih besar, rasa asam dianggap sebagai cacat cita rasa (Sulistyowati 1999).

Setelah melalui manual brew diperoleh hasil keasaman yang cukup. Berdasarkan tingkat penilian panelis melalui hasil pengolahan data dengan menggunakan ANOVA dan uji lanjutan LSD (Least significant differense) serta uji lanjutan turkey's-b dengan selang kepercayaan 95\% atau 0,05 menghasilkan karakteristik acidity yang terpilih pada kode 424 sebesar 4.2000 dengan hasil significant $>0,05$ menyatakan berbeda nyata baik dengan kode 257 maupun dengan kode 633 menurut uji turkey's- $b$. Hasil rata-rata dari uji dapat dilihat pada tabel berikut ini :

Tabel 10.

Deskripsi Hasil Olahan Kuesioner Pada Aspek Acidity

\begin{tabular}{|c|c|c|c|c|c|c|c|c|}
\hline \multirow{2}{*}{ 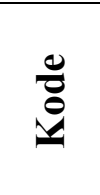 } & \multirow{2}{*}{$N$} & \multirow{2}{*}{ Mean } & \multirow{2}{*}{$\begin{array}{l}\text { Std. } \\
\text { Dev }\end{array}$} & \multirow{2}{*}{$\begin{array}{c}\text { Std. } \\
\text { Error }\end{array}$} & \multicolumn{2}{|c|}{$\begin{array}{l}\text { 95\% Confidence } \\
\text { Interval for Mean }\end{array}$} & \multirow{2}{*}{ Min } & \multirow{2}{*}{$\operatorname{Max}$} \\
\hline & & & & & $\begin{array}{l}\text { Lower } \\
\text { Bound }\end{array}$ & $\begin{array}{l}\text { Upper } \\
\text { Bound }\end{array}$ & & \\
\hline 257 & 50 & 3.2000 & .75593 & .10690 & 2.9852 & 3.4148 & 1.00 & 4.00 \\
\hline 424 & 50 & 4.2000 & .69985 & .09897 & 4.0011 & 4.3989 & 3.00 & 5.00 \\
\hline 633 & 50 & 2.1600 & 1.11319 & .15743 & 1.8436 & 2.4764 & 1.00 & 5.00 \\
\hline Total & 150 & 3.1867 & 1.20617 & .09848 & 2.9921 & 3.3813 & 1.00 & 5.00 \\
\hline
\end{tabular}


Tabel 11.

Uji Anova Pada Aspek Acidity

\begin{tabular}{|l|r|r|r|r|r|}
\hline & $\begin{array}{c}\text { Sum of } \\
\text { Squares }\end{array}$ & Df & $\begin{array}{c}\text { Mean } \\
\text { Square }\end{array}$ & F & Sig. \\
\hline Between Groups & 104.053 & 2 & 52.027 & 67.849 & .000 \\
\hline Within Groups & 112.720 & 147 & .767 & & \\
\hline Total & 216.773 & 149 & & & \\
\hline
\end{tabular}

Tabel 12.

Pengaruh Perbandingan Resep Pada Aspek Acidity

\begin{tabular}{|l|l|l|r|}
\hline & Kode & $\mathrm{N}$ & $\begin{array}{l}\text { Subset for } \\
\text { alpha }=0.05\end{array}$ \\
\hline Tukey & 633 & 50 & 2.1600 \\
\cline { 2 - 4 } $\mathrm{B}^{\mathrm{a}}$ & 257 & 50 & 3.2000 \\
\cline { 2 - 4 } & 424 & 50 & 4.2000 \\
\hline
\end{tabular}

\section{Bitterness}

Rasa pahit (bitterness) adalah citarasa khas lain yang alami yang bisa dikecap dari cokelat. Rasa tersebut berasal dari komponen-komponen alkaloid seperti theobromin dan caffeine, komponen fenolic, pirazin, beberapa peptide, dan asam amino bebas. (Misnawi dan Jinap, 2008 dalam Ramlah 2016:8). Rasa yang dihasilkan tidak terlalu pahit berdasarkan pendapat para panelis.

Sesuai hasil pengolahan data dengan menggunakan ANOVA dan uji lanjutan LSD (Least significant differense) serta uji lanjutan tukey's-b dengan selang kepercayaan $95 \%$ atau 0,05 menghasilkan karakteristik bitterness yang terpilih pada kode 424 sebesar 3.9000 dengan hasil significant $>0,05$ menyatakan berbeda nyata baik dengan kode 257 maupun dengan kode 633 menurut uji turkey's- $b$. Hasil rata-rata dari uji dapat dilihat pada tabel berikut ini :

Tabel 13.

Deskripsi Hasil Olahan Kuesioner Pada Aspek Bitterness

\begin{tabular}{|c|c|c|c|c|c|c|c|c|}
\hline \multirow{2}{*}{ 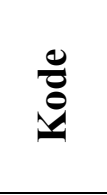 } & \multirow{2}{*}{$\boldsymbol{N}$} & \multirow{2}{*}{ Mean } & \multirow{2}{*}{$\begin{array}{l}\text { Std. } \\
\text { Dev }\end{array}$} & \multirow{2}{*}{$\begin{array}{c}\text { Std. } \\
\text { Error }\end{array}$} & \multicolumn{2}{|c|}{$\begin{array}{l}\text { 95\% Confidence } \\
\text { Interval for Mean }\end{array}$} & \multirow{2}{*}{ Min } & \multirow{2}{*}{$\operatorname{Max}$} \\
\hline & & & & & $\begin{array}{l}\text { Lower } \\
\text { Bound }\end{array}$ & $\begin{array}{l}\text { Upper } \\
\text { Bound }\end{array}$ & & \\
\hline 257 & 50 & 3.1000 & .58029 & .08207 & 2.9351 & 3.2649 & 2.00 & 4.00 \\
\hline 424 & 50 & 3.9000 & .88641 & .12536 & 3.6481 & 4.1519 & 2.00 & 5.00 \\
\hline 633 & 50 & 2.4400 & .67491 & .09545 & 2.2482 & 2.6318 & 1.00 & 4.00 \\
\hline Total & 150 & 3.1467 & .93684 & .07649 & 2.9955 & 3.2978 & 1.00 & 5.00 \\
\hline
\end{tabular}


Tabel 14.

Uji Anova Pada Aspek Bitterness

\begin{tabular}{|l|r|r|r|r|r|}
\hline & $\begin{array}{c}\text { Sum of } \\
\text { Squares }\end{array}$ & Df & $\begin{array}{c}\text { Mean } \\
\text { Square }\end{array}$ & F & Sig. \\
\hline Between Groups & 53.453 & 2 & 26.727 & 50.812 & .000 \\
\hline Within Groups & 77.320 & 147 & .526 & & \\
\hline Total & 130.773 & 149 & & & \\
\hline
\end{tabular}

Tabel 15 .

Pengaruh Perbandingan Resep Pada Aspek Bitterness

\begin{tabular}{|l|l|l|r|}
\hline & Kode & $\mathrm{N}$ & \multicolumn{1}{|c|}{$\begin{array}{l}\text { Subset for } \\
\text { alpha }=0.05\end{array}$} \\
\hline Tukey & 257 & 50 & 3.1000 \\
\cline { 2 - 4 } $\mathrm{B}^{\mathrm{a}}$ & 424 & 50 & 3.9000 \\
\cline { 2 - 4 } & 633 & 50 & 2.4400 \\
\hline
\end{tabular}

\section{E. Astringent (Rasa Sepat)}

Rasa sepat yang menonjol merupakan salah satu cacat serius yang pada cokelat yang disebabkan karena biji tidak terfermentasi. Rasa ini sangat menimbulkan rasa kurang nyaman karena mengganggu saraf di lidah yang seolaholah menyengat dan menimbulkan rasa kering.Hal ini terjadi karena polifenol yang berlebihan pada cokelat berinteraksi dengan protein kaya prolin di air liur dan mengendapkannya. (Misnawi dan Jinap, 2008 dalam Ramlah 2016:8). Rasa dihasilkan sepat kuat namun berimbang dengan pahit dan asam yang ditimbulkan dari hasil manual brew.

Hal ini didukung dengan hasil pengolahan data dengan menggunakan ANOVA dan uji lanjutan LSD (Least significant differense) serta uji lanjutan turkey's- $b$ dengan selang kepercayaan 95\% atau 0,05 menghasilkan karakteristik astringent yang terpilih pada kode 424 sebesar 4.3400 dengan hasil significant $>$ 0,05 menyatakan berbeda nyata baik dengan kode 257 maupun dengan kode 633 menurut uji turkey's- $b$. Hasil rata-rata dari uji dapat dilihat pada tabel berikut ini :

Tabel 16.

Deskripsi Hasil Olahan Kuesioner Pada Aspek Astringent

\begin{tabular}{|c|c|c|c|c|c|c|c|c|}
\hline \multirow{2}{*}{ 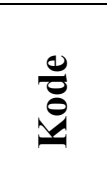 } & \multirow{2}{*}{$N$} & \multirow{2}{*}{ Mean } & \multirow{2}{*}{$\begin{array}{l}\text { Std. } \\
\text { Dev }\end{array}$} & \multirow{2}{*}{$\begin{array}{l}\text { Std. } \\
\text { Error }\end{array}$} & \multicolumn{2}{|c|}{$\begin{array}{l}\text { 95\% Confidence } \\
\text { Interval for Mean }\end{array}$} & \multirow{2}{*}{ Min } & \multirow{2}{*}{$\operatorname{Max}$} \\
\hline & & & & & $\begin{array}{l}\text { Lower } \\
\text { Bound }\end{array}$ & $\begin{array}{l}\text { Upper } \\
\text { Bound }\end{array}$ & & \\
\hline 257 & 50 & 3.1600 & .71027 & .10045 & 2.9581 & 3.3619 & 2.00 & 5.00 \\
\hline 424 & 50 & 4.3400 & .62629 & .08857 & 4.1620 & 4.5180 & 3.00 & 5.00 \\
\hline 633 & 50 & 2.1400 & .88086 & .12457 & 1.8897 & 2.3903 & 1.00 & 4.00 \\
\hline Total & 150 & 3.2133 & 1.16772 & .09534 & 3.0249 & 3.4017 & 1.00 & 5.00 \\
\hline
\end{tabular}


Tabel 17.

Uji Anova Pada Aspek Astringent

\begin{tabular}{|l|r|r|r|r|r|}
\hline & $\begin{array}{r}\text { Sum of } \\
\text { Squares }\end{array}$ & Df & $\begin{array}{c}\text { Mean } \\
\text { Square }\end{array}$ & F & Sig. \\
\hline Between Groups & 121.213 & 2 & 60.607 & 108.702 & .000 \\
\hline Within Groups & 81.960 & 147 & .558 & & \\
\hline Total & 203.173 & 149 & & & \\
\hline
\end{tabular}

Tabel 18.

Pengaruh Perbandingan Resep Pada Aspek Astringent

\begin{tabular}{|l|l|l|r|}
\hline & Kode & $\mathrm{N}$ & \multicolumn{1}{|c|}{$\begin{array}{l}\text { Subset for } \\
\text { alpha }=0.05\end{array}$} \\
\hline \multirow{2}{*}{$\begin{array}{l}\text { Tukey } \\
\mathrm{B}^{\mathrm{a}}\end{array}$} & 257.00 & 50 & 3.1600 \\
\cline { 2 - 4 } & 424.00 & 50 & 4.3400 \\
\cline { 2 - 4 } & 633.00 & 50 & 2.1400 \\
\hline
\end{tabular}

\section{F. Caramelly}

Timbulnya rasa caramel pada produk cokelat disebabkan karena selama proses pemanasan terjadi reaksi antara gugus asam amino, peptide, atau protein dengan gugus hidroksil glikosid atau melanoidin (Ramlah 2016:7). Hasil manual brew dari house blend menghasilkan hasil caremelly yang kuat.

Berdasarkan hasil pengolahan data dengan menggunakan ANOVA dan uji lanjutan LSD (Least significant differense) serta uji lanjutan turkey's-b dengan selang kepercayaan 95\% atau 0,05 menghasilkan karakteristik caramel yang terpilih pada kode 424 sebesar 4.2800 dengan hasil significant $>0,05$ menyatakan berbeda nyata baik dengan kode 257 maupun dengan kode 633 menurut uji turkey's-b. Hasil rata-rata dari uji dapat dilihat pada tabel berikut ini :

Tabel 19.

Deskripsi Hasil Olahan Kuesioner Pada Aspek Caramelly

\begin{tabular}{|c|c|c|c|c|c|c|c|c|}
\hline \multirow{2}{*}{ 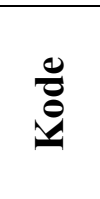 } & \multirow{2}{*}{$N$} & \multirow{2}{*}{ Mean } & \multirow{2}{*}{$\begin{array}{l}\text { Std. } \\
\text { Dev }\end{array}$} & \multirow{2}{*}{$\begin{array}{l}\text { Std. } \\
\text { Error }\end{array}$} & \multicolumn{2}{|c|}{$\begin{array}{l}\text { 95\% Confidence } \\
\text { Interval for Mean }\end{array}$} & \multirow[b]{2}{*}{ Min } & \multirow[b]{2}{*}{$\operatorname{Max}$} \\
\hline & & & & & $\begin{array}{l}\text { Lower } \\
\text { Bound }\end{array}$ & $\begin{array}{l}\text { Upper } \\
\text { Bound }\end{array}$ & & \\
\hline 257 & 50 & 2.9600 & .85619 & .12108 & 2.7167 & 3.2033 & 1.00 & 5.00 \\
\hline 424 & 50 & 4.2800 & .60744 & .08590 & 4.1074 & 4.4526 & 3.00 & 5.00 \\
\hline 633 & 50 & 2.4000 & .83299 & .11780 & 2.1633 & 2.6367 & 1.00 & 5.00 \\
\hline Total & 150 & 3.2133 & 1.10269 & .09003 & 3.0354 & 3.3912 & 1.00 & 5.00 \\
\hline
\end{tabular}


Tabel 20.

Uji Anova Pada Aspek Caramelly

\begin{tabular}{|l|r|r|r|c|c|}
\hline & $\begin{array}{c}\text { Sum of } \\
\text { Squares }\end{array}$ & Df & $\begin{array}{c}\text { Mean } \\
\text { Square }\end{array}$ & F & Sig. \\
\hline Between Groups & 93.173 & 2 & 46.587 & 77.821 & .000 \\
\hline Within Groups & 88.000 & 147 & .599 & & \\
\hline Total & 181.173 & 149 & & & \\
\hline
\end{tabular}

Tabel 21.

Pengaruh Perbandingan Resep Pada Aspek Caramelly

\begin{tabular}{|l|l|l|r|}
\hline & Kode & $\mathrm{N}$ & \multicolumn{1}{|l|}{$\begin{array}{l}\text { Subset for } \\
\text { alpha }=0.05\end{array}$} \\
\hline Tukey & 257 & 50 & 2.9600 \\
\cline { 2 - 4 } $\mathrm{B}^{\mathrm{a}}$ & 424 & 50 & 4.2800 \\
\cline { 2 - 4 } & 633 & 50 & 2.4000 \\
\hline
\end{tabular}

\section{G. Creamy}

Perpaduan antara rasa cokelat yang tajam dengan tekstur yang lembut menghasilkan citarasa creamy yang lebih tinggi. (Ramlah 2016:7). Hasil manual brew dari house blend coklat menghasilkan hasil creamy yang kuat.

Hal ini didukung dengan hasil pengolahan data dengan menggunakan ANOVA dan uji lanjutan LSD (Least significant differense) serta uji lanjutan turkey's-b dengan selang kepercayaan 95\% atau 0,05 menghasilkan karakteristik creamy yang terpilih pada kode 424 sebesar 4.6000 dengan hasil significant $>0,05$ menyatakan berbeda nyata baik dengan kode 257 maupun dengan kode 633 menurut uji tukey's-b. Hasil rata-rata dari uji dapat dilihat pada tabel berikut ini :

Tabel 22 .

Deskripsi Hasil Olahan Kuesioner Pada Aspek Creamy

\begin{tabular}{|c|c|c|c|c|c|c|c|c|}
\hline \multirow{2}{*}{ 苞 } & \multirow{2}{*}{$N$} & \multirow{2}{*}{ Mean } & \multirow{2}{*}{$\begin{array}{l}\text { Std. } \\
\text { Dev }\end{array}$} & \multirow{2}{*}{$\begin{array}{c}\text { Std. } \\
\text { Error }\end{array}$} & \multicolumn{2}{|c|}{$\begin{array}{l}\text { 95\% Confidence } \\
\text { Interval for Mean }\end{array}$} & \multirow{2}{*}{ Min } & \multirow{2}{*}{$\operatorname{Max}$} \\
\hline & & & & & $\begin{array}{l}\text { Lower } \\
\text { Bound }\end{array}$ & $\begin{array}{l}\text { Upper } \\
\text { Bound }\end{array}$ & & \\
\hline 257 & 50 & 3.0000 & .45175 & .06389 & 2.8716 & 3.1284 & 2.00 & 4.00 \\
\hline 424 & 50 & 4.6000 & .49487 & .06999 & 4.4594 & 4.7406 & 4.00 & 5.00 \\
\hline 633 & 50 & 2.0600 & .81841 & .11574 & 1.8274 & 2.2926 & 1.00 & 4.00 \\
\hline Total & 150 & 3.2200 & 1.21440 & .09916 & 3.0241 & 3.4159 & 1.00 & 5.00 \\
\hline
\end{tabular}


Tabel 23.

Uji Anova Pada Aspek Creamy

\begin{tabular}{|l|r|r|r|l|l|}
\hline & $\begin{array}{r}\text { Sum of } \\
\text { Squares }\end{array}$ & Df & $\begin{array}{l}\text { Mean } \\
\text { Square }\end{array}$ & F & Sig. \\
\hline Between Groups & 164.920 & 2 & 82.460 & 221.117 & .000 \\
\hline Within Groups & 54.820 & 147 & .373 & & \\
\hline Total & 219.740 & 149 & & & \\
\hline
\end{tabular}

Tabel 24.

Pengaruh Perbandingan Resep Pada Aspek Creamy

\begin{tabular}{|l|l|l|r|}
\hline & Kode & $\mathrm{N}$ & \multicolumn{2}{|c|}{$\begin{array}{l}\text { Subset for } \\
\text { alpha }=0.05\end{array}$} \\
\hline Tukey & 257 & 50 & 3.0000 \\
\cline { 2 - 4 } $\mathrm{B}^{\mathrm{a}}$ & 424 & 50 & 4.6000 \\
\cline { 2 - 4 } & 633 & 50 & 2.0600 \\
\hline
\end{tabular}

\section{H. Texture}

Penghalusan sangat diperlukan untuk menghasilkan tekstur produk cokelat dan kelembutan (smoothness) cokelat saat dimakan. Melalui penghalusan yang baik, fraksi-fraksi padat dalam cokelat akan menyebar rata dalam fraksi cair (lemak) dan potensi aroma, serta citarasa dan warna khas cokelat tertampakkan. (Misnawi dan Jinap, 2008 dalam Ramlah 2016:9). The real chocolate atau cokelat yang baik memiliki tekstur halus (smooth dan buttery) yang bisa meleleh dengan lembut didalam mulut dengan cita rasa yang kompleks dan menyenangkan (Pangabean, dkk, 2008). Hasil manual brew dari house blend coklat menghasilkan hasil texture yang halus.

Hal ini didukung dengan hasil pengolahan data dengan menggunakan ANOVA dan uji lanjutan LSD (Least significant differense) serta uji lanjutan tukey's-b dengan selang kepercayaan 95\% atau 0,05 menghasilkan karakteristik tekstur yang terpilih pada kode 424 sebesar 4.2600 dengan hasil significant $>0,05$ menyatakan berbeda nyata baik dengan kode 257 maupun dengan kode 633 menurut uji turkey's-b. Hasil rata-rata dari uji dapat dilihat pada tabel berikut ini :

Tabel 25.

Deskripsi Hasil Olahan Kuesioner Pada Aspek Texture

\begin{tabular}{|c|c|c|c|c|c|c|c|c|}
\hline \multirow[b]{2}{*}{$\underset{0}{0}$} & \multirow{2}{*}{$\mathbf{N}$} & \multirow{2}{*}{ Mean } & \multirow{2}{*}{$\begin{array}{l}\text { Std. } \\
\text { Dev }\end{array}$} & \multirow{2}{*}{$\begin{array}{l}\text { Std. } \\
\text { Error }\end{array}$} & \multicolumn{2}{|c|}{$\begin{array}{l}\text { 95\% Confidence } \\
\text { Interval for Mean }\end{array}$} & \multirow{2}{*}{ Min } & \multirow{2}{*}{ Max } \\
\hline & & & & & $\begin{array}{l}\text { Lower } \\
\text { Bound }\end{array}$ & $\begin{array}{l}\text { Upper } \\
\text { Bound }\end{array}$ & & \\
\hline 257 & 50 & 3.1200 & .84853 & .12000 & 2.8789 & 3.3611 & 2.00 & 5.00 \\
\hline 424 & 50 & 4.2600 & .59966 & .08480 & 4.0896 & 4.4304 & 3.00 & 5.00 \\
\hline 633 & 50 & 2.1200 & 1.06215 & .15021 & 1.8181 & 2.4219 & 1.00 & 4.00 \\
\hline Total & 150 & 3.1667 & 1.22292 & .09985 & 2.9694 & 3.3640 & 1.00 & 5.00 \\
\hline
\end{tabular}


Tabel 26.

Uji Anova Pada Aspek Texture

\begin{tabular}{|l|l|l|l|l|l|}
\hline & $\begin{array}{l}\text { Sum of } \\
\text { Squares }\end{array}$ & Df & $\begin{array}{l}\text { Mean } \\
\text { Square }\end{array}$ & F & Sig. \\
\hline Between Groups & 164.920 & 2 & 82.460 & 221.117 & .000 \\
\hline Within Groups & 54.820 & 147 & .373 & & \\
\hline Total & 219.740 & 149 & & & \\
\hline
\end{tabular}

Tabel 27.

Pengaruh Perbandingan Resep Pada Aspek Texture

\begin{tabular}{|l|l|l|r|}
\hline & Kode & $\mathrm{N}$ & \multicolumn{2}{|l|}{$\begin{array}{l}\text { Subset for } \\
\text { alpha }=0.05\end{array}$} \\
\hline Tukey & 257 & 50 & 3.1200 \\
\cline { 2 - 4 } $\mathrm{B}^{\mathrm{a}}$ & 424 & 50 & 4.2600 \\
\cline { 2 - 4 } & 633 & 50 & 2.1200 \\
\hline
\end{tabular}

\section{SIMPULAN DAN SARAN}

Coklat dengan rasa manis yang natural dengan keasaman menyerupai buah berry merupakan karakteristik dari Coklat Java Srawana. Selanjutnya Coklat Lampung Pesawaran, memiliki tekstur yang cukup tebal dengan aroma buah buahan dan rasa pisang yang sangat kuat. Sedangkan Coklat Sulawesi Celebes, memiliki tekstur yang tipis dengan rasa dan aroma vanilla yang lembut. Ketiga single origin ini merupakan kekayaan alam Indonesia yang perlu terus dikreasikan untuk mendapatkan suatu produk yang baik. Proses pembuatan house blend coklat mengahasilkan kombinasi citra rasa baru terhadap sajian minuan coklat. Dengan disajikan menggunakan metode manual brew Cezve ini, dibuat sebanyak 3 resep. Menghasilkan aroma vanila dan rasa pisang yang khas, namun terasa pula rasa sepat namun berimbang dengan pahit dan asam yang ditimbulkan, menghasilkan tekstur yang halus serta terlihat caramelly dan creamy.

Hasil analisa sampel dengan kode 424 memiliki rasa yang lebih baik dari pada sampel 633 dan sampel 257. Pada tingkat kesukaan para panelis memilih sampel 424 menjadi pilihan utama, namun kelemahan pada sampel ini adalah kurangnya aroma yang dihasilkan dengan komposisi single origin coklat Lampung Pesawaran 6gr, Java Srawana 6gr dan Sulawesi Celebes 8gr.

\section{DAFTAR PUSTAKA}

\section{Buku}

Drummond KE \& Brefere LM. 2010. Nutrition for Foodservice and Culinary Professional's, Seventh Edition. New Jersey: John Wiley \& Sons, Inc.

Knox, Kevin. 1997 Coffee Basics: A Quick and Easy Guide. New York: John Wiley \& Sons inc.,

Misnawi dan Jinap, S. (2008). Citarasa, Tekstur, dan Warna Cokelat dalam buku Panduan Lengkap KAKAO. Penebar Swadaya:Jakarta.

Morganelli, Adrianna. (2006). Biography of chocolate. Canada 
Pangabean, T.R., Pujianto, dan Wahyudi, T., (2008), Kakao Manajemen Bisnis dari Hulu Hingga Hilir, Penerbit Penebar Swadaya: Jakarta

Pangabean, T.R., Pujianto, dan Wahyudi, T., (2008), Panduan Lengkap Kakao. Penebar Swadaya. Jakarta

Sugiyono. (2012). Metode Penelitian Kuantitatif Kualitatif dan R\&D. Bandung: Alfabeta.

Sulistyowati. 1999. Uji cita rasa untuk pengujian mutu biji kakao. Warta Pusat Penelitian Kopi dan Kakao 15(3): 324-3

Winarno F.G. 2004. Kimia Pangan dan Gizi. PT Gramedia. Jakarta

\section{Internet}

Jinap S, Dimick PS, Hollender R. 1995. Flavor evaluation of chocolate formulated from cocoa beans from different countries. Journal of Food Control (6) https://agris.fao.org/agris-search/search.do?recordID=US201302898790 Diakses pada 16 November 2019

John. (2015). Manual Brewing : Coffee Glossary http://www.manualcoffeebrewing.com/manual-brewing-coffee-glossary/ Diakses pada 10 Desember 2019

Pashmina.(2016). How to Taste Chocolate Guide https://barandcocoa.com/pages/how-to-taste-chocolate-guide Diakses pada 10 November 2019

Ramlah, Sitti. (2016). Karakteristik Mutu dan Cita Rasaa Cokelat Kaya Polifenol http://ejournal.kemenperin.go.id/bbihp/article/download/3553/2708

Diakses pada 15 Desember 2019.

Paramitha Tasya dan Puspitasari Rintan. (2018). Tak Hanya Kopi, Cokelat Juga Punya Single Origin https://www.viva.co.id/gaya-hidup/kuliner/1060592-tak-hanya-kopi-cokelatjuga-punya-single-origin

Diakses pada 11 Desember 2019

Williams Mc. Mark - 2015, Proceedings of the Oxford Symposium on Food and Cookery, Prospect Books. London.

https://books.google.co.id/books?id=yjZlDwAAQBAJ\&pg=PT10\&source=gb $\mathrm{s}$ toc $\mathrm{r} \& \mathrm{cad}=4 \# \mathrm{v}=$ onepage \&q\&f$=$ false. Diakses pada 16 November 2019

Yusriana dan Rahman Jaya. 2016. Karakteristik Mutu Spesifik Kakao Aceh : Fisik, Kimia dan Sensori. Seminar Hasil Riset dan Standarisasi Industri V, Banda Aceh. Hal 1-10.

http://nad.litbang.pertanian.go.id/ind/index.php/publikasi/jurnal/891karakteristik-mutu-spesifik-kakao-aceh-fisik-kimia-dan-sensori.

Diakses pada 15 Desember 2019. 